\title{
THE NOVEMBER MEETING IN ATHENS
}

The six hundred seventeenth meeting of the American Mathematical Society was held at the University of Georgia at Athens, Georgia on Friday and Saturday, November 20-21, 1964. There were 199 registrants at the meeting.

By invitation of the Committee to Select Hour Speakers for Southeastern Sectional Meetings, Professor John R. Isbell of Tulane University gave an hour address on Structure of Categories. Professor B. J. Ball introduced Professor Isbell. The sessions for contributed papers were presided over by Professors Tomlinson Fort, George Vranceanu, Charles W. McArthur, Ronson J. Warne, James C. Cantrell, and Thomas T. Brahana.

Tallahassee, Florida

O. G. HaRrold, Associate Secretary 